園学雑. (J. Japan. Soc. Hort. Sci.) 54(2) : 171-177. 1985.

$$
\begin{gathered}
\text { ウンシュウミカンに対するエチクロゼートの浮皮軽減 } \\
\text { 効果につ々て } \\
\text { 河 瀬 憲 次 } \\
\text { 果樹試験場興津支場 } 424-02 \text { 静岡県清水市興津中町 } \\
\text { 平井 康市・秃 泰 雄 } \\
\text { 日産化学工業株式会社生物化学研究所 } 349-02 \text { 埼玉県南埼玉郡白岡町 }
\end{gathered}
$$$$
\text { 間 苧谷徹 }{ }^{2}
$$

果樹試験場安芸津支場 729-24 広島県豊田郡安芸津町

Effects of Ethychlozate on Suppressing the Rind Puffing

$$
\text { of Satsuma Mandarin }
$$

\title{
Kenji Kawase
}

Okitsu Branch, Fruit Tree Research Station, Okitsu, Shizuoka 424-02

\author{
Kōichi Hirai and Yasuo Kamuro \\ Nissan Chemical Industry Co., Ltd., Biological and Chemical \\ Research Institute, Shiraoka, Saitama 349-02
}

Tōru Maotani

Akitsu Branch, Fruit Tree Research Station, Akitsu, Hiroshima 729-24

\section{Summary}

The effects of ethychlozate on the rind puffing and its mechanism have been examined in this paper.

Ethychlozate did not show any effect on the rind puffing, when it was used for fruit thinning.

While, ethychlozate substantially suppressed the rind puffing, when it was sprayed at the beginning of coloration.

Since 5-chloro-indazole carboxylic acid, a metabolite of ethychlozate, effectively inhibited the ethylene evolution, this phenomenon may be attributed to the action of this metabolite.

The content of water-soluble pectin decreased, while the content of $0.4 \%$ sodium hexametaphosphate-soluble pectin or $0.05 \mathrm{~N}-\mathrm{HCl}$-soluble pectin increased by application of ethychlozate.

\section{緒 言}

我が国の西南暖地のウンシュウミカンは成熟期の気温 が高いことから，果皮の着色度と果肉熟度のアンバラン スを生じ，かつ高湿なため浮皮になりやすい，浮皮果は 品質や貯蔵性が劣るためその防止策が切望されている.

浮皮発生機構に関しては, 水分代謝, 果皮と果肉の熟

\footnotetext{
1 1984年12月28日 受理

果樹試験場業績番号 B-124

2 現在 農林水産省農林水産技術会議事務局
}

度のアンバランスを生ずる過程，果皮のアルベド組織の 崩壞などの面から考察がなされてきた $(1,5,13,15,22$, 24). まだ浮皮防止などに関しても，熟度と収穫適期，浮 皮になりにくい系統の選抜施肥や水管理の改善, 浮皮軽 減剤の探索などについて検討され，実用技術に至ってい るものもある(8)が，単一の技術による防止策は確立さ れたとはいえない。

エチクロゼート (ethychlozate, Ethyl 5-chloro-3 (IH)-indazolylacetate, J-455, Figaron) は $\beta$ インドー 
ル酢酸と構造が類似し，オーキシン様活性を示す (12). 本剂は1981年以降ウンシュウミカンの摘果剤並びに熟期 促進剤として農薬登録され，実用に供されてきた $(4,7$, 12).

摘果剂として既に実用に供せられていたナフタレン酢 酸（NAA）は, 浮皮を助長する傾向があり(20), 特に浮 皮の発現しやすい西南暖地では一つの難点であった.

そこで エチクロゼートを幼果期から成熟期にかけ て，1回ないし4. 回の反復散布を行った. その結果 NAA とは異なり，浮皮発現を軽減した(12).

多数の既知オーキシン様物質の中で, ウンシュウミカ ンの果実成熟を促進し，かつ浮皮を軽減する物質は本剂 以外に知られていない。

エチクロゼートの浮皮軽減機構を検討した結果, 既報 (18)において認められた浮皮発現とエチレン発生との関 連性が同様にみられたので報告する。

\section{材料及び方法}

1.エチクロゼートの浮皮発現に及ぼす影響

1) 摘果剂散布時期の処理効果

1976 年に果樹試験場口之津支場栽植の 7 年生“シルバ 一ヒル’温州 8 樹を供茑し, エチクロゼート $75 \mathrm{ppm}$ 水溶 液を溞開45日後（6月26日）に, $200 \mathrm{ppm}$ 水溶液を満開 60 日後（7月12日）に散布した. 対照として, NAA 200 $\mathrm{ppm}$ 水溶液を㟨開 30 日後（6月 12 日）に散布した. 両剂の散布時期は各々の摘果剂の使用基準に従った. 処 理は枝別散布とし 8 反復で行った. 7 月29日に葉果比 20 に手值し摘果した．収穫期の 12 月 8 日にM級の果実を各 枝別に 5 果ずつ採収し，各区計 40 果について浮皮度を測 定した。浮皮度は手触りにより, 無: 0 , 軽: 1 , 中 : 2 , 甚: 3 に分別した。浮皮度が 2 及び 3 の果実の割合を浮 皮果発生率とした。

\section{2) 幼果期の処理効果}

1978年に 1) と同一煵場の 9 年生林温州24樹を供試し た. エチクロゼート $100 \mathrm{ppm}$ 水溶液を満開60日後（7 月13日), 同じく 70 日後（ 7 月 24 日）及び80日後 ( 8 月 4 日）の 3 時期に, 各 $1 \sim 3$ 回の処理を組み合わせた 7 区 及び無処理区を設けた (第 1 表). 処理は樹別で 3 反復 とした。供試樹の着果量は 8 月 4 日に手直し摘果し, 葉 果比20〜25に調整した.

\section{3）着色期前後の処理効果}

1979年に 1) と同一围場の10年生林温州39樹を供試し た.エチクロビート $100 \mathrm{ppm}$ 水溶液を着色前の10月 1 日と10月15日，また着色初期の 11 月 1 日及び 3 分着色期 の11月15日の 4 時期に, 各 $1 \sim 4$ 回の処理を組み合わせ
た12区及び無処理区を設けた（第 2 表）. 処理は樹別で 3 反復とした. 12 月 5 日に果実を採収し， 1 樹当たり L 級果12果を選び，果実比重，浮皮度を調査した。

2.エチクロゼートによる浮皮の軽減

1)エチクロゼート散布果実からのエチレ

\section{ン発生量と浮皮発現}

果樹試験場安芸津支場栽植の13年生杉山温州 6 樹を供 試した. エチクロゼート $100 \mathrm{ppm}$ 水溶液を着色開始期 の10月20日に散布した。直後に降雨があったため翌日再 散布した。 その後, 10月28日, 11月10日の計 4 回重復散 布した。散布は樹別とし 3 反復で行った。調查は第 4 回 目散布以後 12 月 3 日まで 5 回果実を採収し, エチレン発 生量を既報(18)の方法に準じて測定した，11月10日と12 月15日には各樹から採収した果実について果実比重を測 定し，12月15日には浮皮度を調查した。

2）エチクロゼート及び代謝産物散布果実 からのエチレン発生量と浮皮発現

神奈川園試根府川分場栽植の藤中系普通温州 9 樹を供 試した。エチクロゼート $100 \mathrm{ppm}$ 水溶液を10月19日, 10月28日の 2 回散布した. 散布は樹別とし 3 反復で行っ た.また，エチクロゼートの代謝産物 (5-chloro-indazole carboxylic acid) $100 \mathrm{ppm}$ 水溶液を10月28日に果実 のみに散布した. 処理は 3 樹で行った. 11月 5 日と11月 18日に果実を採取し，51 の容器に12〜15果ずつ封入し た. $25^{\circ} \mathrm{C}$ 下で16時間放置後，1）と同じ方法でェチレンを 测定した. 同時に果実比重を測定した. 12月 3 日には各 樹より果実を採取し浮皮度を調査した。

3）エチクロゼート散布果実のアルベドの ペクチン含量

1）で調査した果実の果皮から分離したアルベドを凍 結乾燥後, 既報(18)の方法に従い, 水可溶性ペクチン (W-P), ヘキサメタリン酸ナトリウム可溶性ペクチン $(\mathrm{P}-\mathrm{P})$, 及び塩酸可溶性ペクチン $(\mathrm{H}-\mathrm{P})$ を分析した. こ れらの合計を全ペクチン含量とした.

\section{結果}

1.エチクロゼートの浮皮発現に及ぼす影響

1) 摘果剤散布時期の処理効果

摘果剂として散布されたエチクロゼートが，浮皮に及 ぼす影響を調査した結果は第 1 図に示す.

エチクロゼートは摘果剤として使用されたとき，浮皮 発現を抑制することも，また助長することもなく，浮皮 果発生率は無処理区之変わらなかった。一方, 対照の NAA は浮皮果発生率が無処理区より高かった。 
Table 1. Effects of ethychlozate on the quality of satsuma mandarin orange.

\begin{tabular}{|c|c|c|c|c|c|c|c|c|}
\hline \multirow{2}{*}{$\begin{array}{l}\text { Treatment } \\
\text { No. }\end{array}$} & \multicolumn{3}{|c|}{ Time of treatment } & \multirow[b]{2}{*}{ Coloring } & \multirow{2}{*}{$\begin{array}{l}\text { Brix } \\
(\%)\end{array}$} & \multirow{2}{*}{$\begin{array}{l}\text { Citric acid } \\
(\mathrm{g} / 100 \mathrm{ml})\end{array}$} & \multirow[b]{2}{*}{ Brix/acid } & \multirow{2}{*}{$\begin{array}{l}\text { Puffy fruit } \\
(\%)\end{array}$} \\
\hline & $\begin{array}{l}\text { Day } \\
60\end{array}$ & $\begin{array}{l}\text { af ter } \\
70\end{array}$ & $\begin{array}{l}\text { bloom } \\
80\end{array}$ & & & & & \\
\hline 1 & $\bigcirc$ & $x$ & $\times$ & 10. 0 & 12.9 & 1.21 & 10.7 & 50.0 \\
\hline 2 & $\times$ & $\bigcirc$ & $x$ & 9.9 & 12.3 & 1.29 & 9.6 & 55.6 \\
\hline 3 & $x$ & $\times$ & $\bigcirc$ & 10.0 & 12.6 & 1. 27 & 9.6 & 66.7 \\
\hline 4 & $\bigcirc$ & 0 & $\times$ & 10. 0 & 12.8 & 1.15 & 10.0 & 38.9 \\
\hline 5 & 0 & $x$ & $\bigcirc$ & 9.9 & 13. 4 & 1.24 & 11.1 & 44.4 \\
\hline 6 & $\times$ & 0 & 0 & 9.9 & 12.2 & 1.21 & 10.9 & 55.6 \\
\hline 7 & 0 & 0 & 0 & 9.9 & 12.9 & 1.25 & 10.1 & 83.3 \\
\hline 8 & $x$ & $x$ & $x$ & 9.6 & 11.6 & 1. 22 & 10.4 & 72.2 \\
\hline
\end{tabular}

$\bigcirc:$ Ethychlozate treatment at $100 \mathrm{ppm}$

$x$ : no-treatment

Coloring : Coloring of each fruit was rated on a scale of $1-10: 1=$ green $; 10=$ deep orange.

Table 2. Effects of ethychlozate on the rind puffing (The treatment was at the beginning of coloration).

\begin{tabular}{|c|c|c|c|c|c|c|c|c|c|c|c|c|c|}
\hline \multirow{2}{*}{$\begin{array}{c}\text { Treatment } \\
\text { No. }\end{array}$} & \multicolumn{4}{|c|}{ Date of treatment } & \multirow{2}{*}{$\begin{array}{l}\text { Color- } \\
\text { ing }\end{array}$} & \multirow{2}{*}{$\begin{array}{l}\text { Fruit } \\
\text { weight } \\
\text { (g) }\end{array}$} & \multirow{2}{*}{$\begin{array}{l}\text { Specific } \\
\text { gravity } \\
\text { of fruit }\end{array}$} & \multirow{2}{*}{$\begin{array}{l}\text { Degree } \\
\text { of } \\
\text { puffing }\end{array}$} & \multicolumn{4}{|c|}{$\begin{array}{l}\text { Freequency distributions of } \\
\text { puffy fruit }(\%)\end{array}$} & \multirow{2}{*}{$\begin{array}{l}\text { Puffy } \\
\text { fruit } \\
(\%)\end{array}$} \\
\hline & Oct. & Oct. 15 & Nov. 1 & Nov. 15 & & & & & None & Mild & $\begin{array}{l}\text { Inter- } \\
\text { mediate }\end{array}$ & Severe & \\
\hline 1 & 0 & $x$ & $x$ & $x$ & 8.5 & 116 & 0.826 & $1.83 \mathrm{a}$ & 2.8 & 33.3 & 41.7 & 22.2 & $63.9 \mathrm{a}$ \\
\hline 2 & $\times$ & 0 & $\times$ & $x$ & 8.3 & 118 & 0.840 & $1.53 \mathrm{ab}$ & 2.8 & 50.0 & 38.9 & 8.3 & 47. $2 \mathrm{ab}$ \\
\hline 3 & $x$ & $x$ & 0 & $x$ & 8.3 & 114 & 0.829 & 1. $50 \mathrm{abc}$ & 8.3 & 44.4 & 36.1 & 11.1 & 47. $2 \mathrm{ab}$ \\
\hline 4 & $x$ & $x$ & $x$ & 0 & 8.2 & 113 & 0.839 & 1. $25 \mathrm{bc}$ & 19. 4 & 36.1 & 44.1 & 0 & 44. $4 \mathrm{ab}$ \\
\hline 5 & 0 & 0 & $x$ & $x$ & 7.7 & 119 & 0.835 & 1. $31 \mathrm{abc}$ & 11.1 & 52.8 & 30.6 & 5.6 & $36.2 \mathrm{bc}$ \\
\hline 6 & 0 & $x$ & 0 & $x$ & 8.1 & 115 & 0.846 & 1. $19 \mathrm{bc}$ & 16.7 & 50.0 & 30.6 & 2.8 & $33.4 \mathrm{bc}$ \\
\hline 7 & $x$ & 0 & $x$ & 0 & 7.8 & 120 & 0.847 & $0.95 \mathrm{c}$ & 27.8 & 52.8 & 16.7 & 2.8 & $19.5 \mathrm{c}$ \\
\hline 8 & $x$ & 0 & 0 & $x$ & 7.9 & 113 & 0.838 & $0.92 \mathrm{c}$ & 25.0 & 58.3 & 16.7 & 0 & $16.7 \mathrm{c}$ \\
\hline 9 & $\times$ & $x$ & 0 & 0 & 7.9 & 115 & 0.842 & 1. $16 \mathrm{bc}$ & 16.7 & 55.6 & 22.2 & 5.6 & $27.8 \mathrm{bc}$ \\
\hline 10 & $\bigcirc$ & 0 & $\bigcirc$ & $x$ & 8.0 & 120 & 0.846 & $1.00 \mathrm{bc}$ & 19. 4 & 63.9 & 13.9 & 2.8 & $16.7 \mathrm{c}$ \\
\hline 11 & $\times$ & 0 & 0 & 0 & 8.1 & 118 & 0.836 & 1. $42 \mathrm{abc}$ & 16.7 & 41.7 & 25.0 & 16.7 & 41. $7 \mathrm{abc}$ \\
\hline 12 & 0 & 0 & 0 & 0 & 8.5 & 118 & 0.847 & 1. $06 \mathrm{bc}$ & 16.7 & 61.1 & 22.2 & 0 & 22. $2 \mathrm{bc}$ \\
\hline 13 & $x$ & $x$ & $x$ & $x$ & 8.8 & 118 & 0.825 & $1.86 \mathrm{a}$ & 5.6 & 27.8 & 41.7 & 25.0 & $66.7 \mathrm{a}$ \\
\hline
\end{tabular}

$\bigcirc:$ Ethychlozate treatment at $100 \mathrm{ppm}$

$x$ : no-treatment

a, b, $c$ : Mean separation in columns by Dancan's multiple range test at $5 \%$ level.

Coloring : Coloring of each fruit was rated on a scale of $1-10: 1=$ green ; 10=deep orange.

Degree of puffing was classified into 4 ; None $: 0$, Mild $: 1$, Intermediate $: 2$, Severe $: 3$.

\section{2) 幼果期の処理効果}

摘果効果が発現しなくなる満開60日後から80日後にエ チクロゼート処理を行い, 12 月 6 日に果実品質を調查し た結果を第 1 表に示す.

着色度, 糖度はすべての処理区で無処理区の值を上回 った．酸含量には一定の影響が認められなかった．着色 促進，また糖度上昇効果は既に，鈴木ら(21)，Hirose (4), Tominaga ら(23), 及び Kamuro ら(10)によって も認められている.

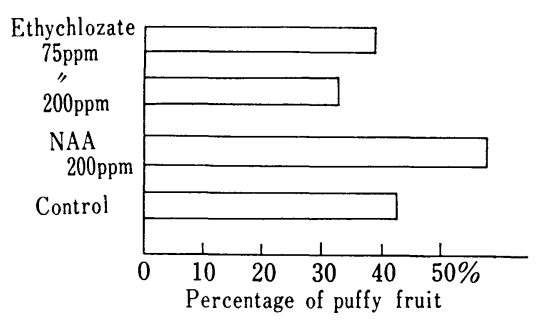

Fig. 1. Effects of ethychlozate and NAA on the rind puffing. The chemicals were sprayed on the young fruit. 
Table 3. Effects of ethychlozate on ethylene evolution, specific gravity and rind puffing.

\begin{tabular}{|c|c|c|c|c|c|c|c|c|c|c|c|}
\hline \multirow{2}{*}{ Treatment } & \multicolumn{5}{|c|}{ Ethylene evolution $\left(\times 10^{-2} \mu \mathrm{l} / \mathrm{fruit} \cdot \mathrm{hr}\right)$} & \multicolumn{2}{|c|}{$\begin{array}{l}\text { Specific gravity } \\
\text { of fruit }\end{array}$} & \multicolumn{4}{|c|}{$\begin{array}{c}\text { Frequency distribution of } \\
\text { puffy fruit }(\%)\end{array}$} \\
\hline & Nov. 4 & Nov. 10 & Nov. 19 & Nov. 25 & Dec. 3 & Nov. 10 & Dec. 15 & None & Mild & $\begin{array}{l}\text { Inter- } \\
\text { mediate }\end{array}$ & Severe \\
\hline Ethychlozate ${ }^{z}$ & 12. 16 & 10. 22 & 17.67 & 16. 11 & 10. 24 & 0.856 & 0.841 & 52.0 & 37.3 & 6.7 & 4. 0 \\
\hline Control & 9.95 & 5.65 & 37.04 & 27.22 & 16. 06 & 0.856 & 0.815 & 21.3 & 37.3 & 25.3 & 16. 0 \\
\hline
\end{tabular}

z Ethychlozate at $100 \mathrm{ppm}$ treatment on Oct. 20, Oct. 21, Oct. 28, Nov. 10.

Degree of puffing was classified into 4 ; None : 0 , Mild : 1 , Intermediate $: 2$, Severe : 3 .

Table 4. Effects of ethychlozate and its metabolite on ethylene evolution, specific gravity and rind puffing.

\begin{tabular}{|c|c|c|c|c|c|c|c|c|}
\hline \multirow{2}{*}{ Treatment } & \multicolumn{2}{|c|}{$\begin{array}{l}\text { Ethylene evolution } \\
\left(10^{-3} \mu \mathrm{l} / \mathrm{fruit} \cdot \mathrm{hr}\right)\end{array}$} & \multicolumn{2}{|c|}{$\begin{array}{l}\text { Specific gravity } \\
\text { of fruit }\end{array}$} & \multicolumn{4}{|c|}{$\begin{array}{l}\text { Frequency distribution of } \\
\text { puffy fruit }{ }^{z}(\%)\end{array}$} \\
\hline & Nov. 5 & Nov. 18 & Nov. 5 & Nov. 18 & None & Mild & Intermediate & Severe \\
\hline Ethychlozate ${ }^{y}$ & 1.63 & 1.75 & 0.871 & 0.840 & 8.1 & 17.7 & 35.5 & 38.7 \\
\hline Metabolite $^{\mathrm{x}}$ & 1.49 & 1.90 & 0.843 & 0.843 & 5.0 & 17.2 & 30.9 & 46.9 \\
\hline Control & 2. 13 & 2.46 & 0.836 & 0.808 & 0 & 14.5 & 24.7 & 60.8 \\
\hline
\end{tabular}

${ }^{z}$ : Harvested on Dec. 3.

$\mathbf{y}:$ Ethychlozate at $100 \mathrm{ppm}$ treatment on Oct. 19 and Oct. 28.

$\mathbf{x}:$ 5-chloro-indazole carboxylic acid.

浮皮果発生率は 3 回散布区で無処理区よりやや高い值 を示したが，1回または 2 回散布のすべての区におい て, 無処理区より低い值を示し, 浮皮軽減の傾向がみら れた。エチクロゼートはNAA と類似のオーキシン様物 質であるが，その作用性は異なるものと推察された。

\section{3）着色期前後の処理効果}

着色期前後の，処理時期と散布回数による効果につい て試験した結果を第 2 表に示す．散布回数と効果につい てみると，1回散布では処理時期を問わず浮皮発現に及 ぽす効果は明らかでなかった，2回以上の散布区では浮 皮発現を軽減する傾向が認められた。 2 回散布区と 3 回 散布区との効果には有意な差はみられなかった，反復処 理の時期と効果についてみると，着色開始期ごろの散布 の効果が高い傾向を示した.

以上の結果から，エチクロゼートは果実着色開始期ご ろに $100 \mathrm{ppm}$ 水溶液を 2 回散布することにより, 有意 に浮皮発現を軽減すると考えられた。

\section{2.エチクロゼートによる浮皮の軽減 \\ 1）エチクロゼート散布果実からのエチレン 発生量と浮皮発現}

結果は第 3 表に示した．果実からのエチレン発生量 は，11月 4 日，11月10日の測定時にはエチクロゼート区 で無処理区より多かった。しかし，11月19日以降，エチ クロゼート区は無処理区より低かった。果実比重は11月 10日では差がなく，12月15日ではェチクロゼート区で無
処理区より高く，また，エチクロゼート区では浮皮度 2〜3の果実が減少し，0の果実が増加した.

2）エチクロゼート及びその代謝産物散布果 実からのエチレン発生量と浮皮発現

エチクロゼート及びその代謝産物処理後の果実からの エチレン発生量を第 4 表に示す.

果実からのエチレン発生量は, 両処理 区とも11月 5 日，11月18日において無処理区より少ない傾向を示し た.エチクロゼート区と代謝産物区とでェチレン発生に 大差なかったが，代謝産物の効果が早く発現する傾向で あった．これはエチクロゼートがオーキシン様物質であ り，このため散布後，数日間ェチレン発生を誘起する (12). しかし，代謝分解が進み 5-chloro-indazole carboxylic acid が生成されるにつれ，この物質によりエチ レン生成が抑制されると推察される(12). したがって, 5-chloro-indazole carboxylic acidを処理した場合，エ チンン発生は早くから低下すると考えられる.

果実比重は11月 5 日，11月18日ともにエチクロゼート 区で高く，ついで代謝産物区，無処理区の順であった. 12月 3 日の収穫果実では浮皮度 3 の果実が減少し，0 1 の果実が増加した.

以上の結果から，エチクロゼート及びその代謝産物の 果実処理により, 成熟期の果実からのエチンン発生量が 低下するとともに, 浮皮発現程度の低下が認められた。 
Table 5. Effects of ethychlozate on the pectin content in albedo.

\begin{tabular}{|c|c|c|c|c|c|}
\hline \multirow{2}{*}{ Date } & \multirow{2}{*}{ Treatment } & \multicolumn{4}{|c|}{$\begin{array}{l}\text { Pectin content } \\
(\% \text { of day weight })\end{array}$} \\
\hline & & $\mathrm{W}-\mathrm{P}^{z}$ & P-Py & $\mathrm{H}-\mathrm{P}^{\mathrm{x}}$ & Total \\
\hline \multirow{2}{*}{ Nov. 4} & Control & 8.41 & 4. 96 & 3. 02 & 16. 39 \\
\hline & Ethychlozate $^{\mathrm{w}}$ & 8.30 & 5.02 & 3.06 & 16. 38 \\
\hline \multirow{2}{*}{ Nov. 25} & Control & 9. 42 & 4.23 & 2.45 & 16.10 \\
\hline & Ethychlozatew & 8.21 & 4. 40 & 3.01 & 15.62 \\
\hline \multirow{2}{*}{ Dec. 4} & Control & 9.40 & 4. 30 & 2.71 & 16. 41 \\
\hline & Ethychlozatew $^{\text {w }}$ & 8.42 & 4. 49 & 3. 31 & 16.22 \\
\hline \multirow{2}{*}{ Dec. 16} & Control & 9.75 & 4. 25 & 2.89 & 16.89 \\
\hline & Ethychlozate $^{\text {w }}$ & 8.83 & 4. 46 & 3. 44 & 16. 91 \\
\hline
\end{tabular}

z: Water-soluble pectin.

y $: 0.4 \%$ sodium hexametaphosphate-soluble pectin.

$\mathrm{x}: 0.05 \mathrm{~N}$ hydrochloric acid-soluble pectin.

w : Ethychozate at $100 \mathrm{ppm}$ treatment on Oct. 20, Oct. 21, Oct. 28, Nov. 10.

\section{3）エチクロゼート散布果実のアルベドのぺ クチン含量}

無処理区のペクチン含量は第 5 表に示すとおり，11月 から12月中旬までの期間における全ペクチンの含量は大 きな変化がみられなかった. ペクチン分画では W-P が 最も多く存在し, 約半量を占め, P-P 区がこれにつぎ, H-P の含量は最も少なかった.

無処理区に比べ浮皮の発生が軽減されたエチクロゼー ト区についてみると、全ペクチン含量では差がなかった が，全ペクチン含量中に占める $\mathrm{W}-\mathrm{P}$ 含量が低 $<, \quad \mathrm{P}-\mathrm{P}$ 及び H-P 含量は高かった (第 2 図).

\section{考察}

本実験の結果，エチクロゼートに浮皮発現を完全に抑 制する作用はないが，実用上十分な経済効果を得るに足 る軽減効果を示した。

浮皮は果皮と果肉の熟度のアンバランス，また果皮の 老化が原因ともみられており(3)，果皮を若く保つこと を目的として，ジベレリンやオーキシン様物質類を与え て浮皮防止を試みた例は多い(6,8,14,16,17). しかし， これらの試みは浮皮抑制効果に伴って着色や果実品質を 低下させる傾向があり，実用化には至っていない(19).

しかしながら，オーキシン様物質であるエチクロゼー 卜は, 従来供試されてきた多数の植物生育調節剤と異な り, 果皮の着色や果肉の熟度を進め, しかも浮皮を軽減 する. 現在のところ, このような現象を示す唯一の物質 としてその作用機構は興味深い。

筆者らは，既にェチレンと浮皮の発現との間に密接な 関係のあることを認めている $(9,18)$. 特にエチレン発生 を抑制する条件下では，浮皮発現も抑制された(18)。そ

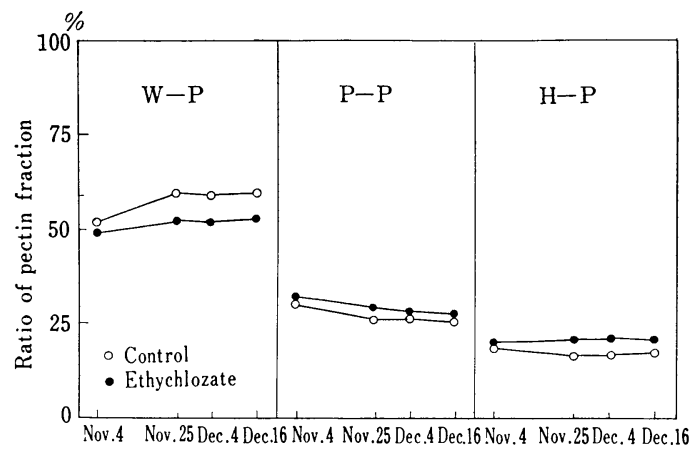

Fig. 2. Changes in the ratio of each pectin fraction in albedo.

こで，本報告においては，エチクロゼートを処理した果 実からのエチレン発生量と浮皮発現との関係を検討し た.

エチクロゼート散布後数日間は果穾からのエチレン発 生量が無処理区より多かったが，その後，長期間にわた って無処理区より低い值を示した。また，既に平田ら （2）によると，エチクロゼートは植物体 内で 5-chloroindazole carboxylic acid を経て代謝分解される. この代 謝産物はエチクロゼート散布後 $1 \sim 2$ 週間で生成され， その植物生理活性はエチクロゼートと異なり，オーキシ ン様活性を示さず，オーキシンの誘導によるエチレンの 生成を阻害することが知られている(11). 代謝産物を果 実処理すると, 処理直後からェチレン発生を抑制し, 収 穫時の浮皮発現を軽減した。

これらの結果から，着色開始期にエチクロゼートを散 布すると，散布後数日間はそのオーキシン様活性により エチレン発生を助長するが，エチクロゼートが代謝さ れ，5-chloro-indazole carboxylic acid が生成されると ともに果実のエチンン発生が抑制されると考えられた。

浮皮現象について, 倉岡ら(15)は果実のアルベド組織 の細胞の発育变形や, フラベド組織中の油胞の吸水膨潤 により，果皮組織が崩壊するものと考察している。この 場合, 細胞壁構成成分（例えばペクチン質）の変化が伴 らと考兄られる. そこで，エチクロゼート処理果実のア ルベドのペクチンを分析したところ，エチクロゼート処 理区では無処理区に比べて水可溶性ペクチン含量が少な く, ヘキサメタリン酸ナトリウム可溶性及び塩酸可溶性 ペクチン含量が高く, 浮皮発現を引き起こす生理変化が 抑制されているのではないかと考兄られる。このことは 既報(18)の結果と一致しており，エチレン生成の抑制が 一因となっているものと推察される。

以上の結果から，エチクロゼートによる浮皮軽減効果 はエチレン発生が抑制されるためと考えられ，今後，浮 
皮の発生機構並びに実用的な浮皮防止策の検討に当たっ ては，エチレンの制御は重要な要因になるものと考えら れる。

\section{摘 要}

エチクロゼートは, ウンシュウミカンの摘果剤並びに 果実成熟促進剂として実用化されているオーキシン様物 質である.ナフタレン酢酸が浮皮を助長したことから， 本剂についても処理時期を変えて浮皮発現に及ぼす影響 とその作用機作を検討した.

1）摘果剂として幼果期に使用した場合，NAA は浮 皮を助長したが，エチクロゼートは浮皮発現に影響しな かった。

2）果実肥大期にエチクロゼートを処理すると，着色 と糖度上昇を促進し，浮皮発現を低下させる傾向がみら れた。

3）着色開始期ごろにエチクロゼートの $100 \mathrm{ppm}$ 水 溶液の 2 回散布により浮皮軽減効果が認められた。

4) エチクロゼートの浮皮軽減効果について検討した ところ, エチクロゼートの代謝分解により生成される 5-chloro-indazole carboxylic acid が果実からのエチレ ン発生量を低下させ，浮皮を軽減させるものと考光られ る。

5）エチクロゼートにより浮皮が軽減された果実で は, 無処理の果実に比べてアルベドの水可溶性画分の含 有率が少なく，ヘキサメタリン酸ナトリウム可溶性及び 塩酸可溶性画分の含有率が多かった.

謝 辞 本研究を行らに当たり，供試樹を提供してい ただき，御指導を賜った神奈川園試根府川分場，真子正 史主任研究員，また御校閲いただいた果樹試験場興津支 場長広瀬和栄博士, 並びに平井正志博士に厚くお礼申し 上げます。

\section{引用 文 献}

1. 赤松 聰. 1976. ミカン園にお打る地力増強と高 品質果の生産. 農及園. $51: 749-753$.

2. 平田博明 - 山口 勇 - 杮木和雄 - 見里朝正. 1980 . みかん用摘果剂エチル 5-クロル-3 $(1-\mathrm{H})$-インダ ゾール酢酸の代謝. 第 1 報. 日本農薬学会第 5 回 大会講演要旨集. 103.

3. 広瀬和策. 1978. 果樹園芸分野に打けるケミカル レギュレーション. 植物の化学調節. 13. 33-43.

4. HiROSE, K. 1981. Development of chemical thinners for commercial use for satsuma mandarin in Japan. Proc. Int. Soc. Citriculture 1981, $1: 256-260$
5. 石井孝昭・水谷房雄・岩崎一男. 1981. カルシウ ム化合物が温州ミカンの浮皮防止に及ぼす影響. 農及園. $56: 809-810$.

6. 河瀬憲次・吉永勝一・内田 誠. 1974. 薬剤によ る温州ミカンの浮皮防止に関する研究. 第 1 報. ジベレリンと炭酸カルシウムの混用効果. 園学要 旨九州支部大会. 昭 $49: 42$.

7. 河瀬憲次. 1981. みかんの新摘果剤. 新しい技術 （農林水産省農林水産技術会議事務局編）19:133 -137 .

8. KAWASE K., K. SUZUKI and K. HiRose 1981. Use of growth regulators to control rind puffing of satsuma mandarin fruit. Proc. Int. Soc. Citriculture 1981, $1: 237-239$.

9. KAWASE, K. and M. HIRAI 1983. Growth, sugar accumulation and puffiness of the mandarin peel during coloring. J. Japan. Soc. Hort. Sci. $52: 231-237$.

10. KAmURO, K. and K. HiraI. 1981. Physiological activity of ethychlozate fruit thinning and maturity accelerating effects for citrus. Pro. Int. Soc. Citriculture 1981, $1: 260-263$.

11. 秃 泰雄・平井康市. 1982. フィガロンの作用性. 第 4 報. 温州みかんの浮皮軽減作用について. 園 学要旨. 昭 57 春 : $16-17$.

12. 秃 泰雄・平井康市. フィガロンの生理作用と利 用開発. 植物の化学調節. $17: 65-70$.

13. 倉岡唯行. 1962. 温州みかん果実の発育に関する 組織学的研究 (特に浮皮の発現機構について). 愛媛大紀要第 6 部 (農学) $8: 106-154$.

14. 倉岡唯行・岩崎一男・門屋一臣. 1966. 温州ミカ ンの浮皮果発現防止に関する研究. 第 5 報. ジべ レリン処理について. 園学要旨. 昭41春 : 43-44.

15. 倉岡唯行 - 岩崎一男 - 日野 昭 - 辻 博美. 1975 . 温州ミカンの浮皮に関する研究. 第 3 報. 果皮内 ペクチン質ならびにカルシウム含量について．園 学雑. $44: 15$ - 21 .

16. KURAOKA, T., K. IWASAKI and T. ISHII 1979. Effects of GA and ethephon on the level of $\mathrm{ABA}$ and peroxidase activity in the peel of satsuma mandarin (Citrus unshiu Marc.) J. Japan. Soc. Hort. Sci. $47: 437-442$.

17. 栗山隆明 - 吉田 守 -下大迫三徳. 1975. 温州 ミ カンの浮皮防止に関する研究. 第 2 報. 植物調節 剂による浮皮防止効果について. 園学要旨九州支 部大会. 昭50：4.

18. 間苧谷 徹・河瀬 憲次・秃 泰雄・平井康市. 1983. ウンシュウミカンの浮皮に及ぼすエチレン の影響. 園学雑. $52: 238-242$.

19. 中野孝美・長田一美. 1967. 温州ミカン浮皮防止 に対するジベレリンの検討. 第 1 報. ジベレリン の作用現象について. 園学要旨. 昭42秋 : 18-19.

20. 中島利幸. 1968. NAA 摘果剂試験. ミカン生育 調節剂試験成績収録. 日本植物生育調節協会. $46: 1-6$. 
21. 鈴木邦彦・広瀬和栄. 1977. カンキツの薬剤摘果 に関する研究. X. ウンシュウミカンに対する J455, TH-656 及び $\mathrm{T}-773$ の摘果効果及び樹の生 育に及ぼす影響。果樹試報. B 4 : 83-98.

22. 鳥潟博高・増井正夫・鈴木 登. 1955. 温州みか んの果皮の発育に関する研究. 第 1 報. 晚期窒素 質施与が果皮の発育に及ぼす影響. 園学研集 7 : 42-48.
23. TOMinaga, S. and H. DaITo. 1981. Effects of ethychlozate on fruit quality of satsuma mandarin (Citrus unshiu Marc.). Pro. Int. Soc. Citriculture 1981, $1: 233-236$.

24. 横尾宗敬 - 奥代直巳 - 小園照雄 - 岩佐俊吉 - 大崎 守. 1963. 温州ミカンの浮皮に関する研究. 第 1 報. 園試報. D $1: 29-44$. 